\title{
Effects of Gibberellic acid and 2,4-Dichlorophenoxy Acetic Acid Spray on Vegetative Growth, Fruit Anatomy and Seed Setting of Tomato (Lycopersicon esculentum Mill.)
}

\author{
Dandena Gelmesa $^{1 *}$, Bekele Abebie $^{2}$ and Lemma Desalegn ${ }^{3}$ \\ ${ }^{1}$ Integrated Seed Sector Development Programme, Haramaya University, Post Box No: 138, Dire Dawa, \\ Ethiopia \\ ${ }^{2}$ Assela School of Agriculture Adama University, Post Box No: 136, Assela, Ethiopia \\ ${ }^{3}$ Ethiopian Seed Growers and Processors Association, Addis Ababa, Ethiopia
}

\begin{abstract}
The experiment was conducted at Melkassa Agricultural Research Center, Ethiopia with the objective to evaluate the effects of different concentrations and combinations of 2,4-dichlorophenoxyacetic acid (2,4-D) and gibberellic acid $\left(G_{3}\right)$ spray on vegetative and reproductive growth components of tomato. The experiment consists of two tomato varieties, one processing (Roma VF) and one fresh market (Fetan), three levels of 2,4-D (0,5 and $10 \mathrm{ppm})$ and four levels of $\mathrm{GA}_{3}(0,10,15$ and $20 \mathrm{ppm})$

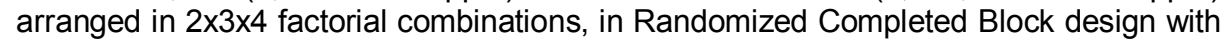
three replications. Data were collected on qualitative parameters (vegetative, reproductive growth and external fruit color) through visual observation, and quantitative parameters (seed number per fruit, seed weight per fruit, fruit shape index and average fruit weight). Qualitative data were analyzed using analysis of variance (ANOVA) by SAS (2002) software and mean separation was carried out by DMRT at $5 \%$ probability level. The result indicated that tomato plant treated with 2,4-D intended to have increased stem thickness, decreased leaf size induced epinastic and flower bud abscission in both cultivars while $\mathrm{GA}_{3}$ treatment has no retarded growth and flower bud abscission. Application of 2,4-D has responsible in the development of seedless parthenocarpic fruit with increased size but with unfilled cavities especially at higher concentration. On the other hand, $\mathrm{GA}_{3}$ at lower concentration results in normal fruit and seed development but as its concentration increases it results in the development of more proportion of smaller fruits per plant and formation of blotchy ripening on the fruit. Combined application of the two PGRs at lowers concentrations seems to result in the intermediate effects of both PGRs in single application. In general, concentration of the PGRs used and genetic background of the variety determine the response of tomato growth, fruit setting, seed formation and final marketable fruit size.
\end{abstract}

Article Information Article History:

Received : 29-06-2013

Revised : 18-09-2013

Accepted : 25-09-2013

\section{Keywords:}

Gibberellic acid

Lycopersicon esculentum,

Vegetative growth

Fruit anatomy

Seed formation

*Corresponding Author:
Dandena Gelmesa
E-mail:
dandenagalmesa@gmail.com

\section{INTRODUCTION}

Tomato (Lycopersicon esculentum Mill.) is the second most important vegetable crops next to potato worldwide. In Ethiopia, tomato is produced throughout the year using irrigation and rain fed. Production is predominantly by small-scale farmers for fresh consumption and commercial farmers for processing industries and export. There are also private owned tomato processing plants, which can process large volume of tomato paste. The crop is one of the most important cash crops to the smallholder farmers (Lemma, 2002), source of vitamins and minerals to tackle micronutrient deficiencies of many household communities in the country. Regardless of available fertile land and irrigation facilities for the production of the crop as well as suitable conditions for export to international markets in the Middle East, Europe and USA, the 


\section{Dandena Gelmesa et al.,}

national production volume is declining due to a number of physical and biological factors.

Normal tomato growth, fruit and seed setting were reported to be affected by environmental, cultural or genetic factors among which light, temperature, nutrition, hormonal imbalance and water supply play a significant role (Kinet and Peet, 1997). According to the authors, for good fruit set and subsequent high yield, pollination, germination of pollen grains, pollen tubes growth, fertilization and fruit initiation must take place successfully. However, high relative humidity of the air, low light intensity and extreme low and high temperature, and improper mineral nutrition seems to be involved in the control of those phenomena and result in low fruit set and quality.

Reproductive developments in tomato including stamen and pollen differentiation and fruit set are important to fruit yield, quality, and dependent on the relative amounts of endogenous growth regulators (Kinet and Peet, 1997). Further, the authors highlighted fruit set in tomato to be critical stage, which is highly affected, by environmental factors and plant growth regulators (PGRs). According to Schwabe (1986), the growth and development of tomato plant can be influenced at most stages of its life cycle by applied growth regulators. Almost all natural growth substances have effects on seed germination, shoot and root growth, side branch development, flowering and truss formation, fruit ripening, and senescence.

Several authors indicated variation in response of tomato plants to both 2,4-D and $\mathrm{GA}_{3}$, concentration of PGRs. Bensen and Zeevaart (1990) indicated that $\mathrm{GA}_{3}$ is more effective on tomato stem growth at concentration of $10 \mathrm{ppm}$ or below. Similarly, Sasaki et al. (2005) indicated application of a mixture of 4-CPA and GAs showed increased tomato fruit set and proportion of normal fruits compared to plants of the same crop treated with 4-CPA alone. The study by Alam and Khan (2002) also showed that sprayed tomato with NAA or $\beta$-NAA at the time of flowering reduced preharvest fruit drop and increased the number of fruits per plant.

Under different environmental conditions, where normal tomato growth is affected by many climatic factors, regulation of vegetative and reproductive growth as well as overcoming of normal pollination and fertilization for fruit development can be induced and manipulated through the use of PGRs like 2,4-D and $\mathrm{GA}_{3}$. In line with this, preliminary report indicated that, applying the ethylene releasing PGR (ETHREL) under field condition at Nura Era farm, Ethiopia, in 1984 showed that the yield collected at one picking was more than doubled regardless of
Sci. Technol. Arts Res. J., July-Sep 2013, 2(3): 25-34

the applied concentrations compared to the control (Heussler and Ayele, 1987). This clearly indicates that PGRs could improve tomato fruit earliness and yield under Ethiopian condition and might have commercial importance. However, these PGRs have not been exhaustively studied and there is lack of information regarding type, rate and time of application. This study was therefore initiated to assess the effects of different concentrations and combinations of gibberellic acid and 2,4dichlorophenoxy acetic acid sprays on vegetative growth, fruit anatomy and seed setting of two tomato cultivars.

\section{MATERIALS AND METHODS}

The experiment was conducted at Melkassa Agricultural Research Center, Ethiopia which is located at $8^{\circ} 24^{\prime} \mathrm{N}$ latitude, $39^{\circ} 21^{\prime} \mathrm{E}$ longitude and at an altitude of 1550 meters above sea level, in the middle rift valley of Ethiopia. The area is characterized by low and erratic rainfall with mean annual rainfall of $796 \mathrm{~mm}$ with peaks in July and August. The dominant soil type of the center is Andosol of volcanic origin with $\mathrm{pH}$ that ranges from 7 to 8.2 . The mean annual temperature is $21.2^{\circ} \mathrm{C}$ with a minimum of $14^{\circ} \mathrm{C}$ and maximum of $28.4^{\circ} \mathrm{C}$ (MARC, 2008).

Two improved tomato varieties Roma VF and Fetan, were obtained from Melkassa Agricultural Research Center, used as a test material. Roma VF is processing type, compact and strong stem with determinate growth habit, having oval shaped and fruit size of 50-60 gram, maturity time of 74 days and yield potential of 40 ton $\mathrm{ha}^{-1}$ (MARC, 2003) while Fetan is fresh market type released in 2005, adapted to an altitude range of 500-2000 meters above sea level, with strong stem, determinate growth habit having cylindrical shaped and fruit size of 114 gram with yield potential of 45 ton ha ${ }^{-1}$ (MoARD, 2006). Commercial tissue culture grade of $\mathrm{GA}_{3}\left(\mathrm{C}_{19} \mathrm{H}_{22} \mathrm{O}_{6}\right)$ powder with $95 \%$ purity and 2,4-D $\left(\mathrm{C}_{8} \mathrm{H}_{6} \mathrm{Cl}_{2} \mathrm{O}_{3^{-}}\right.$CSA No 94-75) powder (salt formulation) were obtained from Sigma Chemical Co Ltd, Germany used for the experiment. The two tomato varieties, three levels of 2,4-D $(0,5$ and 10 ppm) and four levels of $\mathrm{GA}_{3}(0,10,15$ and $20 \mathrm{ppm})$ are arranged in a $2 \times 3 \times 4$ factorial combinations, in randomized complete block design with three replications. Seedlings were raised in mid August in an open nursery bed. Ridomil ${ }^{\circledR} \mathrm{MZ} 68 \mathrm{WP}$ at a rate of $2.5 \mathrm{~kg} \mathrm{ha}^{-1}$ and Cocide at a rate of $2 \mathrm{~kg} \mathrm{ha}^{-1}$ were sprayed on the nursery beds every 14 days interval to control damping off and bacterial spot, respectively. The seedlings were transplanted to the experimental field after 35 days at a spacing of 30 $\mathrm{cm}$ between plants on ridges having $100 \mathrm{~cm}$ width. A net plot size of $12 \mathrm{~m}^{2}(4 \mathrm{~m} \times 3 \mathrm{~m})$ having 40 plants plot $^{-1}$ was used. A total of 20 plants per plot were 


\section{Dandena Gelmesa et al.,}

considered for data collection from the two middle rows. The field was irrigated using furrow irrigation when rainfall was not sufficient for plant growth. Urea as a source of nitrogen fertilizer was applied at a rate of $46 \mathrm{~kg} \mathrm{ha}^{-1}$ in split form, half at transplanting and half at first flowering as a side dress. Phosphorous fertilizer was applied at a rate of $40 \mathrm{~kg}$ $\mathrm{ha}^{-1}$ all at transplanting using di-ammonium phosphate as a side dress. Weeding, cultivation and pest control were done manually following previous recommendations (Lemma, 2002). The required weight of the PGRs was taken using electronic sensitive balance (model BOSCH SAE200) and a stock solution was prepared by dissolving $1 \mathrm{ml}$ of 97 percent ethanol. Latter the stock solution was diluted in distilled water $\left(\mathrm{dH}_{2} \mathrm{O}\right)$ to prepare the working solutions, just before application. Tween-20 at the rate of $0.05 \%(\mathrm{v} / \mathrm{v})$ was added before spray and mixed well to act as cohesive agent. The solution was poured into hand-held atomizer sprayer and was directly sprayed on the plants at early flowering (42 days after transplanting). Spraying was performed early in the morning to avoid rapid drying of the spray solution, due to transpiration.

Data were collected from randomly selected plants in the two middle rows. For vegetative and fruit anatomy visual observation were employed using 1-5 scale (where 1 indicating no modified effect on vegetative and reproductive growth compared to the control and 5 reveals the presence of thick and decreased stem length, curled leaves, flower bud abscission), examination of fruit anatomy such as parthenocarpic fruit development, fruit cavity, spot ripening and elongated blossom end). Quantitative data on seed number per fruit, seed weight per fruit $(\mathrm{g})$, fruit weight $(\mathrm{g})$, and fruit shape index were collected and analyzed using analysis of variance (ANOVA) by SAS (2002) software and mean separation was carried out by DMRT at $5 \%$ probability level. Descriptive methods were used to present quantitative data.

\section{RESULTS}

\section{Effect on Leaf, Stem and Flower Development}

Tomato plants treated with either 2,4-D, GA $A_{3}$ or their combinations at different concentration showed differential growth on both varieties. The representative samples of plant growth affected by the treatments were illustrated in Figure 1. Plants treated with 2,4-D intended to have increased stem thickness and decreased leaf size differentially for Roma VF (Figure 1A) and Fetan (Figure 1B). It also resulted in induced epinastic and flower bud abscission in both cultivars (Figure 1C). There was no reduction in leaf size and stem length and flower abscission due to $\mathrm{GA}_{3}$ treatment compared to the
Sci. Technol. Arts Res. J., July-Sep 2013, 2(3): 25-34

controls and 2,4-D treated plants (Figure 1D and E) for both varieties. Tomato plants treated with combination of 2,4-D and $\mathrm{GA}_{3}$ recovered from growth retardation and had better vegetative growth as compared with application of 2,4-D alone. In case of Roma VF incidence of flower bud abscission was minimum compared to Fetan, which seems to regulate the vegetative and reproductive growth pattern for better fruit yield and quality (Figure 1E).

\section{Effect on Internal and External Fruit Anatomy}

When considering the effect of 2,4-D and $\mathrm{GA}_{3}$ on fruit development, fruits from untreated tomato plants develop normally with filled locular tissue and seed formation (Figure 2A). However, the cavities of fruit treated with 2,4-D at 5 and $10 \mathrm{ppm}$ and $\mathrm{GA}_{3}$ at $10 \mathrm{ppm}$ were not filled or with less number of seeds and had deformed shape particularly when the concentration of 2,4-D increased to $10 \mathrm{ppm}$ (Figure 2B). Visual observation of the external fruit color indicated that there was external fruit color variation observed due to the treatments effect at harvest (Figure 2C). Gibberellic acid at higher concentration $(20 \mathrm{ppm})$ resulted in higher proportion of uneven ripening fruits and remained with green spot on the fruit even after harvest. This kind of fruit development is locally named as "renjer" and has low market value and most of the time rejected at farm get price. Comparing the two varieties, Roma VF showed increased intensity of parthenocarpic fruit development with much more unfilled cavities and had elongated blossom end (Figure 2B and F). Fetan was relatively insensitive to parthenocarpic fruit development due to the two applied PGRs and with filled cavities better than Roma VF with no elongated blossom end (Figure 2E).

However, combined application of both PGRs resulted in reduced intensity of poor cavity parthenocarpic fruit setting than 2,4-D application alone. Increased concentration of $\mathrm{GA}_{3}$ resulted in smaller fruit sizes especially in the last harvests having oblong and pear shaped proximal end (Figure 2D) even thought more fruit numbers per plant were obtained. Fruit shape index, which is the ratio of fruit width to fruit length decreased when the proportion of fruit length increased at a greater proportion as compared to fruit width. This study also resulted significant $(P<0.05)$ decrease in fruit shape index due to application of 2,4-D and $\mathrm{GA}_{3}$ (Table 1).

\section{Effect on Seed Number and Weight per Fruit and Fruit Size}

Highly significant $(P<0.01)$ interaction effects of variety, 2,4-D and $\mathrm{GA}_{3}$ on number of seeds per fruit were indicated. In the absence of 2,4-D, application 

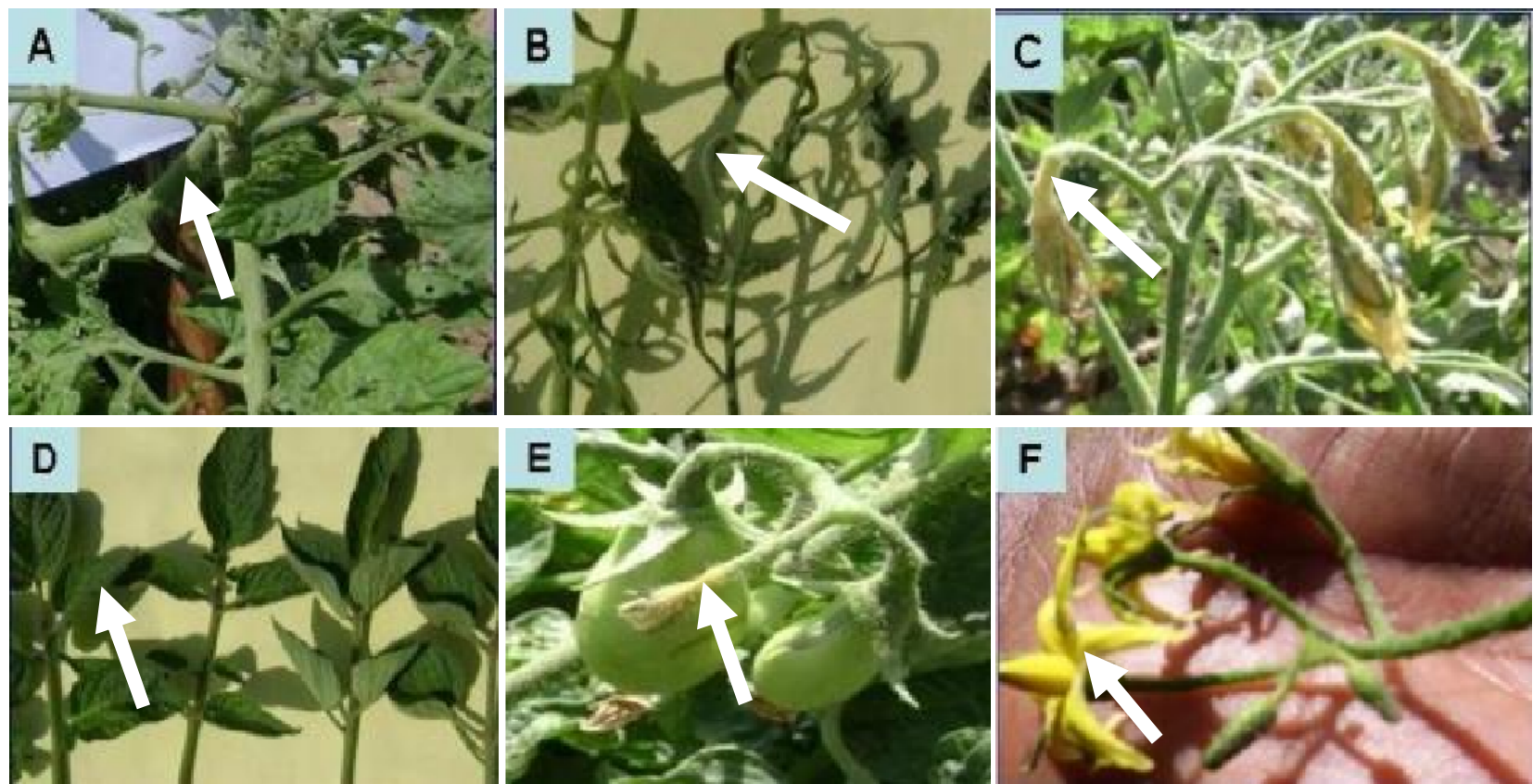

$\mathrm{A}$ and B-Increased in stem thickness, reduced stem length and leaf curvature for variety Roma VF and Fetan, respectively due to application of 2,4-D at $10 \mathrm{ppm}$; C-Flower bud abscission (variety Fetan) due to application of 2,4-D at 10 ppm; D-Normal leaf growth similar to the control (variety Roma VF) when $\mathrm{GA}_{3}$ alone applied at all concentrations; EFlower bud abscission (Roma VF) due to 2,4-D spray at $10 \mathrm{ppm}$; F-Normal flower development (variety Roma VF) similar to the control when $\mathrm{GA}_{3}$ applied alone at all concentrations.

Figure 1: Vegetative and reproductive growth performance of tomato plants as affected by 2,4-D and $\mathrm{GA}_{3}$ spray at Melkassa, Ethiopia.

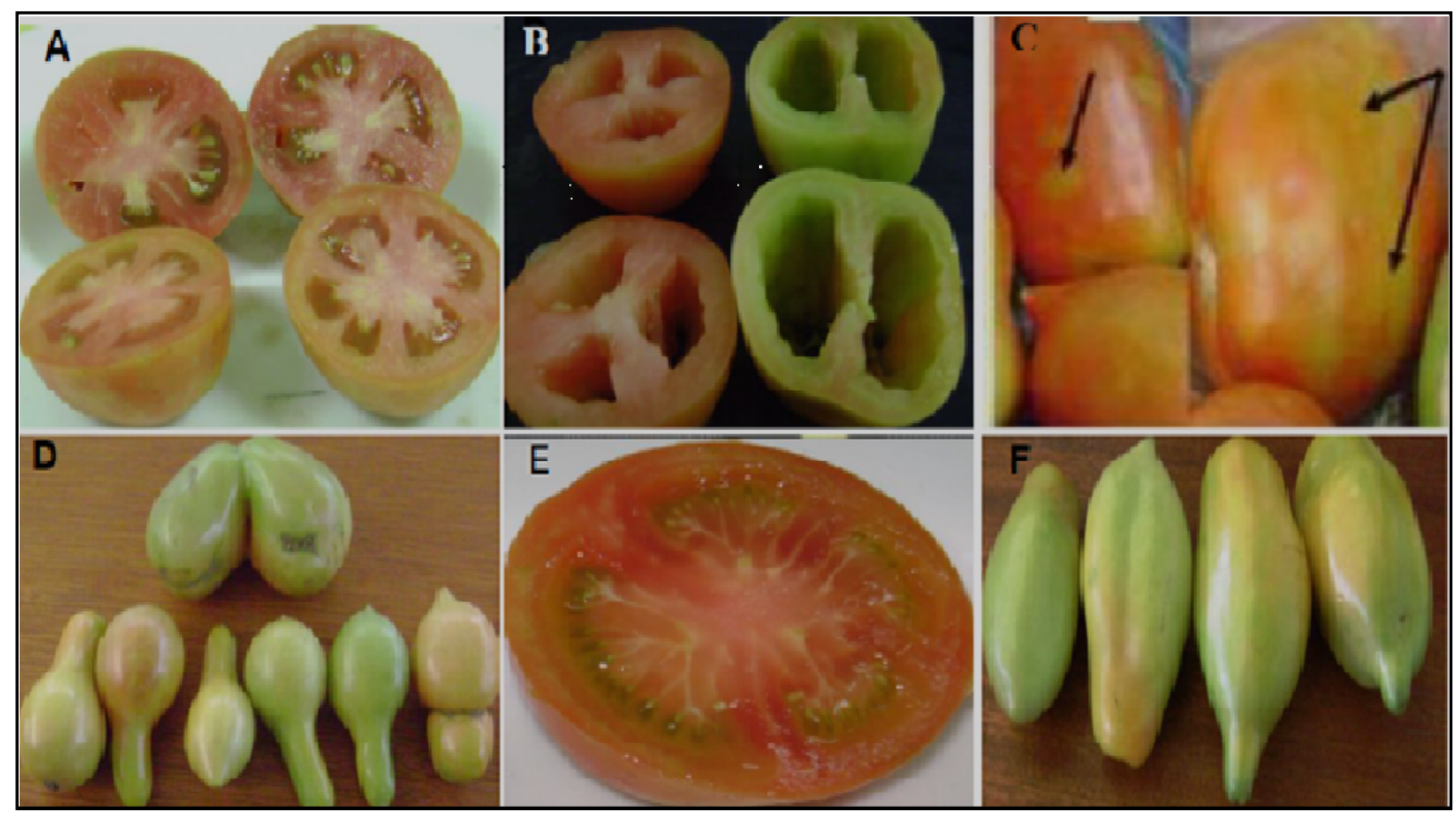

A-Normal fruit developed from control treatment (variety Fetan); B-Internal fruit anatomy (variety Roma VF) when 2,4-D applied at $10 \mathrm{ppm}$; C-External fruit with spots formation during ripening (variety Fetan) when $\mathrm{GA}_{3}$ sprayed at $20 \mathrm{ppm}$; DFruit developed (variety Roma VF) when $20 \mathrm{ppm} \mathrm{GA}$ applied; E-Internal fruit anatomy (variety Fetan) when 2,4-D Sprayed 10 ppm; F-Elongated blossom end fruit development (variety Roma VF) when 2,4-D applied at 10 ppm.

Figure 2: Effects of 2,4-D and $\mathrm{GA}_{3}$ spray on internal and external fruit morphology of tomato grown at Melkasa, Ethiopia. 
Dandena Gelmesa et al.,

Table 1: Effects of variety, 2,4-D and $\mathrm{GA}_{3}$ spray on seed weight fruit ${ }^{-1}(\mathrm{~g}) \&$ fruit shape index of tomato plants grown at Melkassa, Ethiopia.

\begin{tabular}{|c|c|c|}
\hline Treatment & $\begin{array}{l}\text { Seed Weight } \\
\text { Fruit }^{-1}(\mathrm{~g})\end{array}$ & $\begin{array}{l}\text { Fruit Shape } \\
\text { Index }\end{array}$ \\
\hline \multicolumn{3}{|l|}{ Variety } \\
\hline Roma VF & $0.2047 \mathrm{~b}$ & $0.634 b$ \\
\hline Fetan & $0.2959 a$ & $0.919 a$ \\
\hline F-test & $* * *$ & $* * *$ \\
\hline \multicolumn{3}{|l|}{ 2,4-D (ppm) } \\
\hline 0 & $0.2884 a$ & $0.791 a$ \\
\hline 5 & $0.2411 \mathrm{~b}$ & $0.764 b$ \\
\hline 10 & $0.2215 b$ & $0.775 \mathrm{ab}$ \\
\hline F-test & $* *$ & * \\
\hline \multicolumn{3}{|l|}{$\mathrm{GA}_{3}(\mathrm{ppm})$} \\
\hline 0 & $0.2565 a$ & $0.799 a$ \\
\hline 10 & $0.2129 b$ & $0.768 b$ \\
\hline 15 & $0.2583 a$ & $0.769 b$ \\
\hline 20 & $0.2736 a$ & $0.771 \mathrm{~b}$ \\
\hline F-test & * & * \\
\hline CV (\%) & 24.56 & 4.12 \\
\hline
\end{tabular}

*, **, *** significant at $5 \%, 1 \%$ and $0.1 \%$ probability level; ns-non significant at $5 \%$ probability level; Means followed by the same letter within a column are not different from each other according to DMRT at prescribed probability level
Sci. Technol. Arts Res. J., July-Sep 2013, 2(3): 25-34

of $10 \mathrm{ppm} \mathrm{GA}_{3}$ significantly reduced the number of seeds per fruit from 114 to 96 in Fetan, while no significant difference was observed in Roma VF, compared with the control (Figure 3). Application of $\mathrm{GA}_{3}$ at $20 \mathrm{ppm}$ significantly increased the number of seeds per fruit in Fetan from 96 to 126 as compared to application of $10 \mathrm{ppm} \mathrm{GA}_{3}$, which resulted in $31.25 \%$ increments of seed number per fruit. Increasing concentration of 2,4-D from 5 to $10 \mathrm{ppm}$ significantly resulted in decreased seed number per fruit from 79 to 41 . When 2,4-D at both concentrations applied with $\mathrm{GA}_{3}$, seed number per fruit increased with increased concentration of $\mathrm{GA}_{3}$. However, the two varieties responded differentially as far as seed setting is concerned in response to 2,4-D and $\mathrm{GA}_{3}$.

Seed weight was significantly affected by variety $(P<0.001)$, 2,4-D $(P<0.01)$ and $\mathrm{GA}_{3}(P<0.05)$ (Table 1). Comparing the two varieties, Fetan resulted in greater seed weight $(0.2959 \mathrm{~g})$ per fruit compared to Roma VF which gave the lowest seed weight of $0.2047 \mathrm{~g}$ per fruit. 2,4-D both at 5 and $10 \mathrm{ppm}$ significantly reduced seed weight per fruit by $16.4 \%$ and $23.2 \%$, respectively as compared to the control. On the other hand, $\mathrm{GA}_{3}$ decreased significantly $(P<0.05)$ seed weight per fruit when applied at 10 ppm while its effect on seed weight at 15 and 20 ppm were non-significant compared to the control. This indicates that $\mathrm{GA}_{3}$ seems to be an important PGR that improve seed number and seed weight per fruit in tomato especially at a concentration of 15 and $20 \mathrm{ppm}$.

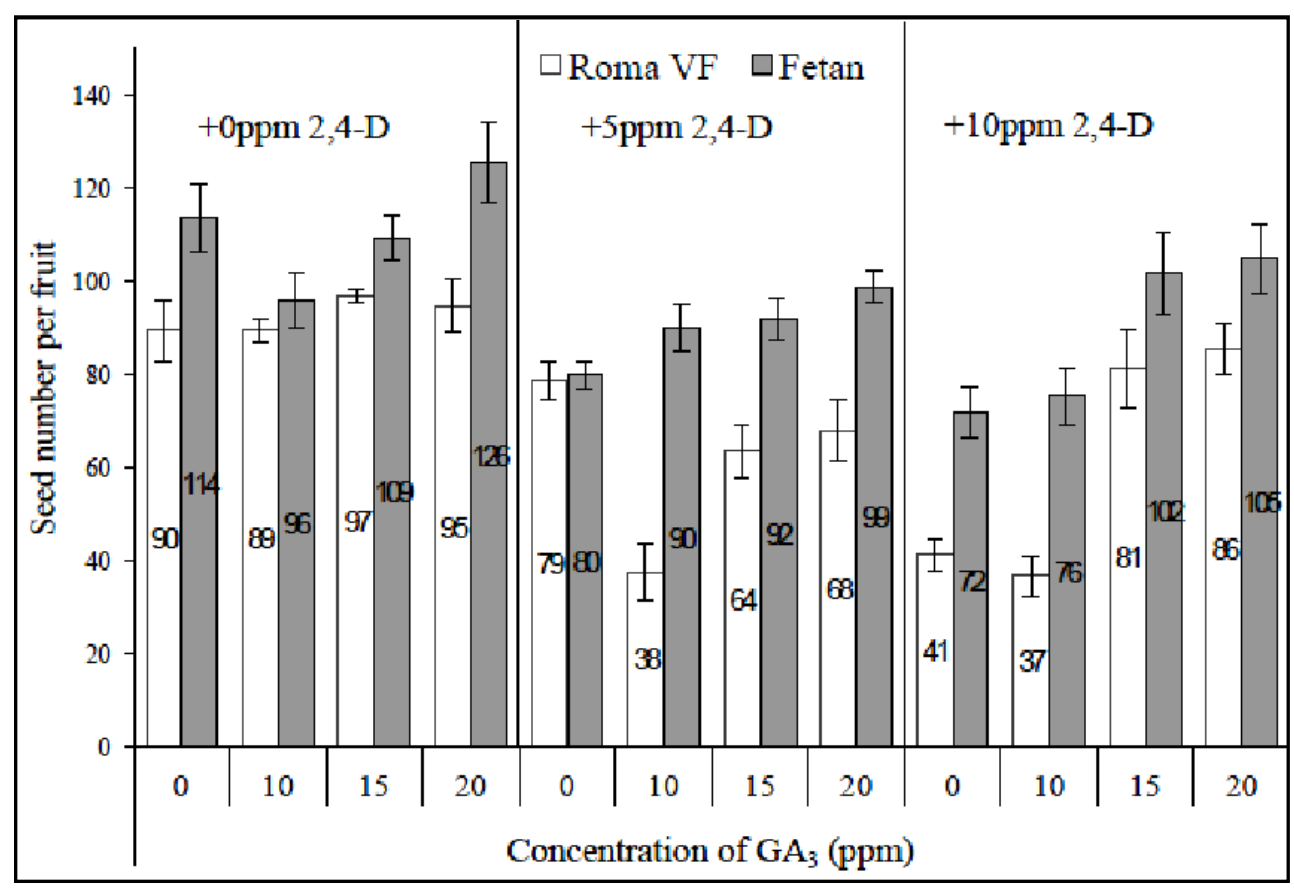

Figure 3: Interaction effects of variety, 2,4-D and $\mathrm{GA}_{3}$ on seed number per fruit (value inside the graph) of tomato plants grown at Melkassa, Ethiopia. Bars are \pm SE (mean). 


\section{Dandena Gelmesa et al.,}

Seed is an important organ sink responsible for the development of plant tissue. In line with this, fruit size under application of 2,4-D and $\mathrm{GA}_{3}$ revealed that the two PGRs showed an increasing trend in fruit size regardless of seed number and weight in the fruit (Figure 4) compared to the control treatments. Maximum fruit weight of $89.31 \mathrm{~g}$ were
Sci. Technol. Arts Res. J., July-Sep 2013, 2(3): 25-34

recorded for variety Fetan at combined application of 2,4-D (both at $5 \mathrm{ppm}$ and $10 \mathrm{ppm}$ ) and $\mathrm{GA}_{3}$, respectively. For variety Roma VF maximum fruit weight $(55.94 \mathrm{~g})$ were obtained at $10 \mathrm{ppm}$ 2,4-D application. The lowest fruit weight of $41.85 \mathrm{~g}$ and $72.75 \mathrm{~g}$ were recorded for variety Fetan and Roma $V F$, respectively from the control treatments.

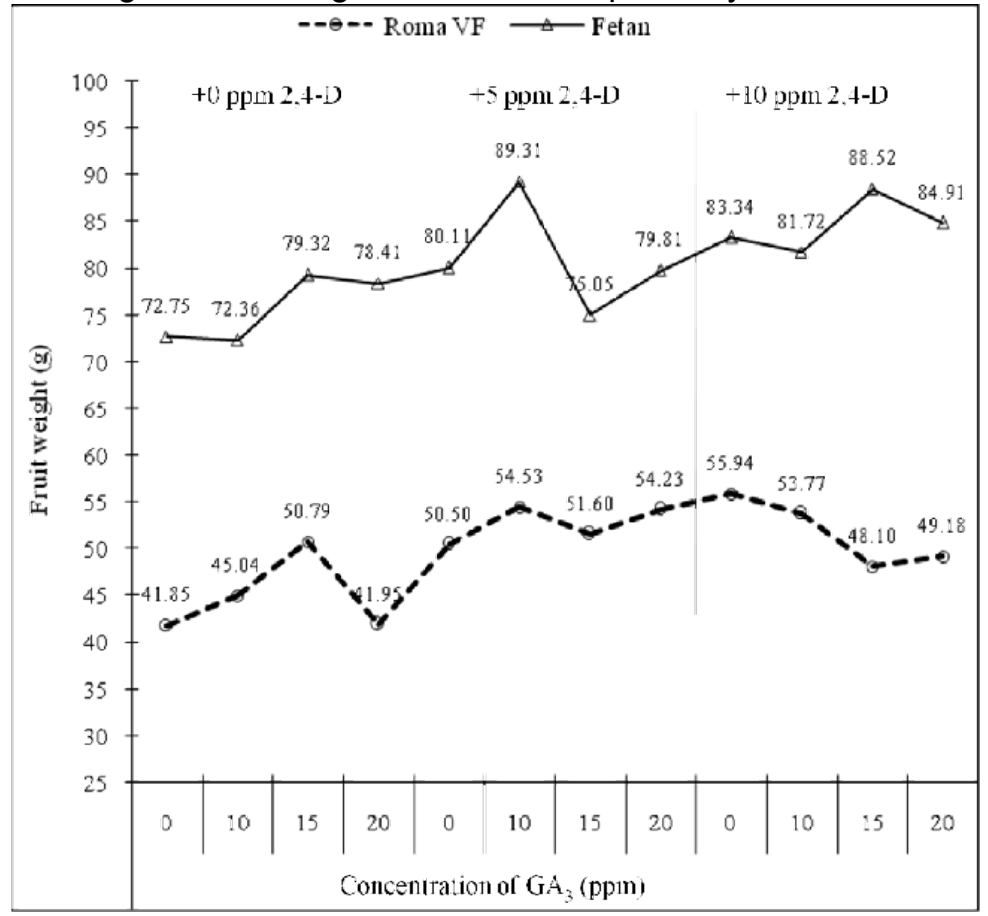

Figure 4: Interaction effects of variety, 2,4-D and $\mathrm{GA}_{3}$ spray on fruit weight $(\mathrm{g})$ of tomato varieties Roma VF and Fetan grown at Melkassa, Ethiopia

\section{DISCUSION}

\section{Effect on Leaf, Stem and Flower Development}

From morphological observation, we were able to examine stimulation of growth and subsequent reproductive organ formation in tomato plants treated with $\mathrm{GA}_{3}$ compared to plants treated with 2,4-D. Similar to this investigation, application of $\mathrm{GA}_{3}$ increased tomato plant height even after the end of hormone treatment and has positive effect on petal elongation and inflorescence stalk length both in wild type and pat mutants of tomato plants (Muzzucato et al., 1998) although the final size of fruits and seed set was not significantly affected by the hormone. On the other hand, the extent of hormone induced floral modifications also depends on the genetic background (Sawhney, 1983) of the plant which corroborates the difference observed between Roma VF and Fetan in the intensity of vegetative growth modefication. Gemici et al. (2000) indicated that $10 \mathrm{ppm} \mathrm{GA}$ treated plants showed a $17 \%$ increase in stem length when compared to the control. Stimulation of increased plant height by $\mathrm{GA}_{3}$ is defined characteristics of this hormone (Scott, 1984). It is quite effective in increasing fruit size, especially in grapes, and is used for stimulating the growth of sugar cane (Graham and Ballesteros, 1980). Furthermore, the authors indicated that stimulation of plant growth by $\mathrm{GA}_{3}$ was ascribed to stimulation of cell division and cellular elongation. Brown et al. (2005) also indicated that, single applications of very small amount of $\mathrm{GA}_{3}$ to seeds or seedling roots proved to be capable of changing growth rates of leaves and trusses.

On the other hand, the effects of 2,4-D on leaf, stem and flower development of tomato is more or less opposite effect as compared to $\mathrm{GA}_{3}$. In line with this findings, Serrani et al. (2007) indicated that high doses of 2,4-D resulted in some malformations in tomato. This malformations could be due to over expression of IAA-biosynthesis genes (Pandolfini et al., 2002), while small epidermal protuberances that were never found in pollinated and $\mathrm{GA}_{3}$ induced fruits were produced. The report of Ashton and Crafts (1981) further indicated that growth inhibitions may be direct when caused by direct interference with cell division or cell enlargement or indirect when caused by a deficiency of metabolic substrates for growth. Furthermore, the authors emphasized that auxin like herbicides (2,4-D) cause initiation of cell division and enlargement in certain mature parenchyma cells leading to massive tissue proliferation while inhibiting cell division in apical meristems. Foliar spray of 2,4-D on tomato plant 


\section{Dandena Gelmesa et al.,}

also support this idea that intensity of leaf curling, reduced stem growth and increased flower bud abscission were greater at especially high concentration of 2,4-D spray compared to $\mathrm{GA}_{3}$.

Comparing the two varieties, Fetan was more sensitive to 2,4-D spray and indicated malformed growth than Roma VF, hence its leaves were damaged severely and much of its flower buds abscised. In Roma VF incidence of foliage injury and flower bud abscission were minimal and seems to regulate the vegetative and reproductive growth pattern for increased fruit yield and quality (Dandena et al., 2010; Dandena et al., 2012). This indicates that optimum concentrations of PGRs that promote vegetative growth and yield could be different for different varieties, whether they are determinate or indeterminate types or specific site application especially in the case of 2,4-D could be important.

\section{Effect on Internal and External Fruit Anatomy}

Variation in internal and external fruit anatomy observed in this study indicates that tomato varieties may respond differently to different PGRs application for final fruit growth and development. On the other hand, application of PGRs plays a role in inducing parthenocarpy and/or supporting the development of naturally induced parthenocarpy to develop and attain maximum marketable fruit number and size. The present findings of parthenocarpic fruit development with increased fruit size could be advantageous for tomato production under adverse climatic condition where normal fruit setting is difficult through pollination and fertilizations. Corella et al. (1986) indicated that most parthenocarpic fruits that set naturally may fail to reach marketable fruit size because of lack of seeds, which greatly reduced their sink activity. However, they further suggested that such failure of fruit swelling can be reduced by applying synthetic auxins and GA, which improve fruit growth thereby increasing the percentage of marketable fruits number per plant. The quality attributes of parthenocarpic fruit in most report also indicated that it has higher levels of soluble solids and sugar, but lower level of acid compared with seeded fruits (Ho and Hewitt, 1986).

However, increased concentration of both PGRs has adverse effect either in reducing fruit size and external fruit quality (due to $\mathrm{GA}_{3}$ ) or reducing the number of fruit per plant due to flower bud abscission and elongated blossom end formation (due to 2,4-D spray at $10 \mathrm{ppm}$ ). Similar to the present findings, Gimici et al. (2006) reported that 2,4-D resulted in increased tomato fruit size, fresh and dry weight when used at recommended concentration. On the other hand, application of $\mathrm{GA}_{3}$ can cause increased fruit set and growth of normal
Sci. Technol. Arts Res. J., July-Sep 2013, 2(3): 25-34

fruits and seed development but with small fruit size in the case of Roma VF or leads to spot formation on external fruit of variety Fetan as its concentration is increasing to $20 \mathrm{ppm}$. In addition to their role in anthesis and stimulate fruit and seed development (Srivastava and Handa, 2005), $\mathrm{GA}_{3}$ can prevent flower abortion caused by low light intensities and enhance latter development of flower buds (Nester and Zeevaart, 1988). Another possible reason that can be ascribed for the reduction in fruit weight and size of the tomato fruits at high concentrations of $\mathrm{GA}_{3}$ could be due to stimulation of shoot growth (Elfying, 1984; Bakrim et al., 2007) and suppressing the growth of developing fruit lets (Luckwill, 1978) which leads to more competition for assimilates. High GA levels detected in young, immature tomato fruits (Koornneef et al., 1990) which may play a role in anthesis, stimulate fruit, and seed development (Rebers et. al., 1999).

$\mathrm{GA}_{3}$ spray at excessive concentration ( $\left.\mathrm{Ho}, 1998\right)$ may enhance the deposition of calcium oxalate in pericarp tissue cause blotchy (spot) ripening on tomato fruit. However, the intensity of blotchy ripening was high and observed very well in variety Fetan than Roma VF. As reported by Ho (1998), there is a wide range of susceptibility to blotch ripening among the modern cultivars. An attractive deep red color is a major quality attribute for tomato products; however, color spot disorder appears in both under warm and cool seasons. The symptoms appear as yellowish spots during summer and dark green during winter on pepper fruit surface (Rylski and Aloni, 1994). Based on the above information and the report by Afaf et al. (2007) which indicated that $\mathrm{GA}_{3}$ significantly increased the percentage of nitrogen, potassium, and protein in the leaves in Globe Artichoke, increased $\mathrm{GA}_{3}$ concentration may involve in nitrogen uptake in tomato plant, which could be result in development of color spots on ripening fruits. Uniform and deep red external fruit color is one of the quality components in tomato attracting buyers. Hence, high concentration of $\mathrm{GA}_{3}$ at $20 \mathrm{ppm}$ had adverse effect on normal fruit size development and enhanced the development of color spot on ripening fruit. However, Dandena et al. (2010) reported that other fruit quality component like lycopene content (pigment responsible for red color fruit) was not affected due to application of $\mathrm{GA}_{3}$ at different concentrations as compared to the control fruit that having normal fruit with filled cavity and seed formation. On the other hand significant reduction in fruit shape index observed due to 2,4-D and $\mathrm{GA}_{3}$ spray indicates that both PGRs increased fruit length at greater proportion compared to the control than fruit width. Such change in fruit shape index in tomato due to hormonal effect may affect market value of the fruit as consumers prefer round fruits. However; external appearance of the fruits 


\section{Dandena Gelmesa et al.,}

may be of less importance if tomato is to be used for crushing and processing (Ram, 2005).

\section{Effect on Seed Number and Weight per Fruit and Fruit Size}

Various phytohormones, including GAs, cytokinin, and auxin, are involved in the growth and development of both seeds and fruit (Swain et al., 1997; Fos et al., 2000, 2001). However, effects of PGRs on tomato seed development directly related to the cultivars' ability to set naturally seeded fruits (Kepcka, 1966). For instance, increased concentration of 2,4-D reduced number of seeds per fruit while $\mathrm{GA}_{3}$ reversed the effect of 2,4-D in most of the cases and improved seed setting except at 15 and $20 \mathrm{ppm}$ according to this experiment. This is in agreement with the reports of Abad and Monteiro (1989). The authors reported that application of auxins significantly reduced the number of normal seeds and increased both the number of aborted seeds per fruit and the proportion of parthenocarpic fruits. It is a well-known fact that seeds play an important role in regulating fruit growth and development. According to the report of Nowaczyk and Nowaczyk (2000) treating tomato flowers with PGRs resulted in setting the fruits with smaller number of seeds or in extreme cases, in setting seedless fruits which coincide with the findings of this study especially when 2,4-D sprayed at 5 and $10 \mathrm{ppm}$.

Bradford et al. (2003) indicated that regulation of LeSNF4 expression by ABA and GA provides a potential link between hormonal and sugar-sensing pathways controlling seed development, dormancy, and germination. Gibberellic acid besides improving seed yield (Prasad et al., 2008) it also improves seed germination of pumpkin and latter improved seed development, greater accumulation of food reserves resulting in higher quality seeds. Similar results were recorded by Goudappalavar (2000) in tomato. A single application of $\mathrm{GA}_{4+7}$ restored the fertility of the mutant flowers and resulted in seed pollination of ga-1/ga-1 flowers with wild type or ga1 pollen respectively (Groot et al., 2008).

According to the current study, fruit size increment regardless of seed number and seed weight could attributed due to the fact that the two PGRs responsible for cell division and subsequent fruit enlargement. This increased fruit enlargement (weight) responsible for final increased fruit yield and other quality components (Dandena et al., 2010). The study by Serrani et al. (2007), suggested also that simultaneous application of $\mathrm{GA}_{3}$ and 2,4-D produced parthenocarpic fruits similar to pollinated fruits, but for the absence of seeds, suggesting that both kinds of hormones are involved in the induction of fruit development upon pollination.
Sci. Technol. Arts Res. J., July-Sep 2013, 2(3): 25-34

Exogenous application of auxins to emasculated tomato flowers transiently increased the rate of cell division compared to the pollinated control (BüngerKibler and Bangerth, 1983), and resulted in fruit that was similar in size to the seeded fruits. Furthermore, they reported that application of $\mathrm{GA}_{3}$ increased cell enlargement, but decreased cell division throughout tomato fruit development compared to the pollinated control which resulted in fruit that was significantly smaller than the seeded fruit. Our study also supports this idea to some extent that $\mathrm{GA}_{3}$ at high concentration reduced fruit weight in the case of Roma VF.

On the other hand, $\mathrm{GA}_{3}$ plus auxin is less effective for increasing tomato fruit growth than auxin (Monteiro, 1983). The effect of 2,4-D in our study in inducing longer fruits with bigger size and weight is also in agreement with the work of Khan et al. (2006). The authors reported an increase in fruit weight due to 2,4-D application which could be also due to stimulation of parthenocarpic fruit growth by PGR that resulted in increased fruit weight.

Nowaczyk and Nowaczyk (2000) reported that decrease in number of seed in fruits accompanied by production of smaller amount of jelly surrounding the seeds which may affect juice volume for processing tomato. However, under this experiment either $2,4 \mathrm{D}$ or $\mathrm{GA}_{3}$ in single or combined application resulted in significant variation in fruit juice volume (data not present) as compared to the control treatment but it improved fruit pericarp thickness which may contribute to juice volume, TSS ( ${ }^{\circ} \mathrm{Brix}$ ) and TA (\%) (Dandena et al., 2010). On the other hand, incompetent use of PGRs especially in very high concentration may lead to the phenomena known as "pepperishness", which means a complete lack of jelly and fruit chamber filled with air. This phenomenon was observed in fruits obtained from Roma VF plants treated with $10 \mathrm{ppm}$ 2,4-D but not in Fetan. Use of appropriate concentration, type and rate of PGRs based on tomato cultivars responding to the PGRs under use to minimize its adverse effect on fruit quality is advisable without focusing only on yield increments.

\section{CONCLUSION}

The response and susceptibility of tomato plant to PGRs in vegetative and reproductive organ development, parthenocarpic fruit and seed formation particularly 2,4-D may vary depending on the genetic background of the plant. Fetan was more susceptible to 2,4-D spray even in combined application with $\mathrm{GA}_{3}$ in vegetative growth and flower bud development but in the case of parthenocarpic fruit setting Roma VF is more responsive. This clearly indicates that the effective concentration of these PGRs to improve tomato fruit yield and quality 


\section{Dandena Gelmesa et al.,}

depends on the chemical nature of the PGRs used and the tomato cultivar. Use of those PGRs beyond the recommended concentrations may affect the plat growth negatively and final fruit yield and quality. These synthetic substances should be used only at tested and recommended concentrations in order to preserve quality crop product that are safe and health for the consumer instead of focusing on short term gains of high yield.

Induction of parthenocarpic fruit without natural pollination and fertilization, the increase in fruit size by the use of 2,4-D and $\mathrm{GA}_{3}$ and its superior quality components similar or even better than seeded fruit could be exploited by commercial growers and processing industries through production of tomato under harsh condition using PGRs.

\section{ACKNOWLEGMENTS}

The authors would like to thank Melkassa Agricultural Research Center, Haramaya University Department of Plant Sciences and Detscher Akedemischer Austauschdienst(DAAD) for material and financial support during this research work.

\section{REFERENCES}

Abad, M., and Monteiro A.A. (1989). The use of auxins for the production of greenhouse tomatoes in mild-winter conditions: A review. Scientia Horticulturae 38:167192.

Afaf, T.M.K, Abd El-hameid A.M. and El-Greadly N.H.M. (2007). A comparison study on the effect of some treatments on earliness, yield and quality of globe artichoke (Cynara scolymus L.). Research Journal of Agriculture and Biological Sciences 3: 695-700.

Alam, S.M. and Khan M.A. (2002). Fruit yield of tomato as affected by NAA spray. Asian Journal of Plant Sciences 1(1): 24.

Ashton, F.M. and Crafts A.S. (1981). Mode of Action of herbicides, $2^{\text {nd }}$ edition. John Wiley and Sons Inc. Pp. 525.

Bakrim, A., Lamhamdi M., Sayah F. and Chibi F. (2007). Effects of plant hormones and 20-hydroxyecdysone on tomato (Lycopersicon esculentum) seed germination and seedlings growth. African Journal of Biotechnology 6: 2792-2802.

Bensen, R.J. and Zeevaart J.A.D. (1990). Comparison of ent-kaurene synthetase A and B activities in cell-free extracts from young tomato fruits of wild-type and gih1, gih-2, and gih-3 tomato plants. Journal of Plant Growth Regulators 9:237-242.

Bradford, K.J., Downie A.B., Gee O.H., Alvarado V., Yang H. and Daha P. (2003). Abscisic acid and gibberellin differentially regulate expression of genes of the SNF1-related kinase complex in tomato seeds. Plant Physiology 132:1560-1576.

Brown, M.E., Jackson R.M. and Burlingham S.K. (2005). Effects produced on tomato plants, Lycopersicon esculentum, by seed or root treatment with GA \& indol-
Sci. Technol. Arts Res. J., July-Sep 2013, 2(3): 25-34

3-acetic acid. Journal of Experimental Botony 19: 544552.

Bunger-Kibler, S. and F. Bangerth, 1983. Relationship between cell number, cell size and fruit size of seeded fruits of tomato (Lycoperesicon esculentum Mill.), and those induced parthenocarpically by the application of plant growth regulators. Plant Growth Regulators 1: 143-154.

Corella, P., Cuartero J., Nuez F. and Bḡuena M. (1986). Development time of parthenocarpic tomato (Lycopersi -con esculentum Mill.) fruits chemically and genetically induced. Journal of Horticultural Sciences 61: 103-108.

Dandena Gelmesa, Bekele Abebie and Lemma Desalegn (2010). Effects of Gibberellic acid and 2,4dichlorophenoxy acetic acid spray on fruit yield and quality of tomato (Lycopersicon esculentum Mill.) Journal of Plant Breeding and Crop Sciences 2(10):316-324.

Dandena Gelmesa, Bekele Abebie and Lemma Desalegn (2012). Regulation of tomato (Lycpersicon esculentum Mill.) fruit setting and earliness by application of gibberellic acid and 2,4-dichlorophenoxy acetic acid in the central rift valley of Ethiopia. African Journal of Biotechnology 11(51):11200-11206.

Elfving, D.C. (1984). Factors affecting apple tree response to chemical branch induction treatments. Journal of the American Society for Horticultural Science 109: 476481.

Fos, M., Nuezand F. and Garcia-Martinez J.L. (2000). The gene, pat-2, which induces natural parthenocarpy, alters the gibberellin content in unpollinated tomato ovaries. Plant Physiology 122: 471-480.

Fos, M., Proaño K., Nuez F.and García-Martínez J.L. (2001). Role of gibberellins in parthenocarpic fruit development induced by the genetic system pat-3/pat4 in tomato. Plant Physiology 111: 545-550.

Gemici, M., Güve A. and Yürekli A.K. (2000). Effect of some growth regulators and commercial preparations on the chlorophyll content and mineral nutrition of Lycopersicon esculentum Mill. Turkish Journal of Botony 24:215-219.

Gemici, M., Türkyilmaz B. and Tan K. (2006). Effect of 2,4-D and 4-CPA on yield and quality of the tomato, Lycopersicon esculentum Mill. JFS 29: 24-32.

Goudappalavar, H.B. (2000). Effect of mother plant nutrition and chemical spray on seed yield and quality in tomato (Lycopersicon esculentum Mill.). M.Sc. (Agri) Thesis, University of Agricultural Sciences, Dharwad, India.

Graham, H.D. and Ballesteros M. (1980). Effect of plant growth regulators on plant nutrients, Journal of Food Science 45: 502-508.

Groot, S.P., Bruinsma C.J. and Karssen C.M. (2008). The role of endogenous gibberellin in seed and fruit development of tomato: Studies with a gibberellindeficient mutant. Physiologia Plantarum 71: 184-190.

Heussler, P. and Ayele Onke (1987). Development of Tomato Production in Ethiopia. In: Godfrey-SamAggrey W. and Bereke-Tsehai Tuku (eds.). 


\section{Dandena Gelmesa et al.,}

Proceedings of the First Ethiopian Horticultural Workshop. Institute of Agricultural Research, 20-22 February 1985. Addis Ababa Ethiopia.

Ho, L.C. (1998). Improving Tomato Fruit Quality by Cultivation. Pp 17-29. In Cockshull K.E., Gray D., Seymour G.B. and Thomas B. (eds.). Genetic and Environmental Manipulation of Horticultural Crops. CABI Publishing.

Ho, L.L. and Hewitt J.D. (1986). Fruit Development. Pp 201-233. In: Atherton J.G. and Rudich J. (eds). The Tomato Crop. A Scientific Basis for Improvement. Chapman and Hall.

Kepcka, A.K. (1966). The use of auxin sprays or artificial pollination in order to improve fruit setting of tomatoes grown under glass. Acta Horticulturae 4:55-62.

Kinet, J.M. and Peet M.M. (1997). Tomato. Pp 207-248. In H.C Wien (ed.). The Physiology of Vegetable Crops. $\mathrm{CAB}$ International.

Khan, M.M.A, A.C. Gautam, F. Mohammad, M.H. Siddiqui, M. Naeem and M.N. Khan, 2006. Effect of gibberellic acid spray on performance of tomato. Turkish Journal of Biology 30: 11-16.

Koornneef, M., Bosma T.D.G., Hanhart C.J., van der Veen J.H. and Zeevaart J.A.D. (1990). The isolation and characterization of gibberellin-deficient mutants in tomato. Theoretical and Applied Genetics 80: 852-857.

Lemma Dessalegn. (2002). Tomatoes. Research Experience and Production Prospects. Research Report 43. Ethiopian Agricultural Research Organization Addis Ababa, Ethiopia. Pp.48.

Luckwill, L.C. (1978). The chemical induction of early cropping fruit trees. Acta Horticulturae 65: 139-145.

MARC (2008). Melkassa Agricultural Research Center. Ethiopian Institute of Agricultural Research, Center Profile, Melkassa, Ethiopia. Pp.12.

MARC (2003). Melkassa Agriculture Research Center. Handout Prepared for Trainees of SORPARI. Melkassa. Pp.89.

Mazzucato, A., Taddei A.R., Soressi G.P. (1998). The parthenocarpic fruit (pat) mutant of tomato (Lycopersicon esculentum Mill.) sets seedless fruits and has aberrant anther and ovule development. Development 125:107-114.

MoARD (2006). Ministry of Agriculture and Rural Development, Crop Variety Register. Crop development department, Issue No. 8. Addis Ababa Ethiopia. 140-145p.

Monteiro, A.A., 1983. Tomato fruit growth in relation to methods of improving fruit-setting. Acta Horticulturae 137: 307-314.

Mostafa, E.A.M. and Saleh M.M.S. (2006). Influence of spraying with gibberellic acid on behavior of Anna Apple trees. Journal of Applied Sciences Research 2: 477-483.

Nester, J.E. and Zeevaart J.A.D. (1988). Flower development in normal tomato and a gibberellin deficient (ga-2) mutant. American Journal of Botony 75:45-55.
Sci. Technol. Arts Res. J., July-Sep 2013, 2(3): 25-34

Nowaczyk, P. and Nowaczyk L. (2000). The effect of growth regulators on tomato (Lycopersicon esculentum Mill.) fertility. Acta Physiologiae Plantarum 22:309-311.

Pandolfini. T, Rotino G.L., Camerini S., Defez R. and Spena A. (2002). Optimization of transgene action at the post-transcriptional level: High quality parthenocarpic fruits in industrial tomatoes. $B M C$ Biotechnology 2:1-11.

Prasad, C.T.M., Sajjan A.S., Vyakaranahal B.S., Nadaf H.L. and Hosamani R.M. (2008). Influence of nutrition and growth regulators on fruit, seed yield and quality of pumpkin cv. Arka Chand, Karnataka Journal of Agricultural Sciences 21: 115-117.

Ram, H.H., (2005). Vegetable Breeding Principles and Practices, $2^{\text {nd }}$ edition. Kalyani Publishers, LudhianaNew Delhi. 653p.

Rebers, M., Kaneta T., Kawaide H., Yamaguchi S.and Yang Y.Y. (1999). Regulation of gibberellin biosynthesis genes during flower and early fruit development of tomato. The Plant Journal17:241-250.

Rylski, I. and Aloni B. (1994). Flowering, fruit set, hit development and fruit quality under different environmental conditions in tomato and pepper crops. Acta Horticulturae 366: 45-56.

SAS. (2002). Statistical Analysis System. SAS institute version 9.00 Cary, NC, USA.

Sasaki, H., Yano T. and Yamasaki A. (2005). Reduction of high temperature inhibition in tomato fruit set by plant growth regulators. JARQ 39:135-138.

Sawhney, V.K. (1983). The role of temperature and its relationship with gibberellic acid in the development of floral organs of tomato (Lycopersicon esculentum). Canadian Journal of Botany 61:1258-1265.

Sawhney, V.K. (1983). The role of temperature and its relationship with gibberellic acid in the development of floral organs of tomato (Lycopersicon esculentum). Canadian Journal of Botany 61: 1258-1265.

Schwabe, W.W. (1986). Possible application of growth regulators in tomato production. Acta Horticulturae 190: 309-314.

Scott, T.K. (1984). Functions of hormones at the cellular level of organization. The functions of hormones from the level of the cell to the whole plant. Encyclopedia of Plant Physiology New Series, 10, Springer-Verlag, New York, Heidelberg, Berlin, Tokyo.

Serrani, J.C., Fos M., Atare's A. and Garcl'a-Martı'nez J.L. (2007). Effect of gibberellin and auxin on parthenocarpic fruit growth induction in the cv MicroTom of tomato. Journal of Plant Growth Regulators 26: 211-221.

Srivastava, A. and Handa A.K. (2005). Hormonal regulation of tomato fruit development: A molecular perspective. Journal of Plant Growth Regulators 24: 67-82.

Swain, S.M., Reid J.B. and Kamiya Y. (1997). Gibberellins are required for embryo growth and seed development in pea. The Plant Journal 12:1329-1338. 